\title{
IMPLICATIONS FOR FEDERALISM OF THE REFORMED CONSTITUTION OF CANADA
}

\author{
RICHARD H. LEACH*
}

The reform of the Canadian Constitution in 1982 has profound implications for the functioning not only of the national government but of those of the provinces as well. In some respects the new constitution breaks new ground, so that it will be some time before the full impact of constitutional change in the provinces can be assayed.

Even though the necessity of central authority has always been begrudgingly acknowledged, the theme of local rights has been played over the years as stridently as it has been south of the Canadian border-and with much greater effect. In recent years especially, the Canadian governmental piper has been increasingly harkening to the tune of that theme. The purpose of this paper is to examine how the reformed Canadian Constitution may affect the federal-provincial dance in the future.

That dance must first be understood in historical terms, for the past was very much a factor in the negotiations leading to agreement on the terms of the reformed constitution. If anything stands out in Canadian history since 1867, it is the power of the provincial presence on the Canadian governmental stage. Even at the outset, the script for the confederation drama was written by provinces. Indeed, the patriated constitution of Canada continues the long tradition of a compact among the provinces as the basis of the Canadian state.

The development of that tradition need not be traced at any great length. Historians generally agree that the resolutions which were essentially enacted by the British Parliament and together served as Canada's first Constitution as the British North America Act of 1867 ' ("BNA Act") were regarded by the representatives from Canada East and Canada West as a treaty, a compact between the two founding peoples of Canada, and that the original idea of a "racial compact" was later transformed into a geopolitical compact. As G.F.G. Stanley summed it up: "the meeting of the maritime [sic] delegates with those of Canada at Charlottetown and at Quebec introduced a new interpretation which has had mighty impact upon the course of our later history, namely, the idea of a compact between the politico-geographic areas which go to make up Canada."'2 Stanley concluded that the "Compromise of Quebec became a compact between the provinces which

\footnotetext{
Copyright (C) 1983 by Law and Contemporary Problems

* Department of Political Science and Canadian Studies Center, Duke University.

1. British North America Act, 1867, 30 \& 31 Vict., ch. 3 [hereinafter cited as BNA Act].

2. Stanley, Act ar Pact? Another Look at Confederation, in Canadian Historical Readings 94, 106 (1967).
} 
participated in the conference,"3 and the London Resolutions, which incorporated those made in Quebec with little substantive change and were submitted to Parliament, did nothing to alter "the contractual nature of the pact."4

For their part, members of the British Parliament also accepted the idea of a provincial compact. Charles Adderley, M.P., who introduced what was to become the BNA Act to the House of Commons, told the House that federation had "in this case . . been a matter of most delicate mutual treaty and compact between the provinces." 5 Lord Carnavon said almost the same thing to the House of Lords. ${ }^{6}$

In other words, the immediate predecessor of the patriated constitution was the product of provinces negotiating as provinces. It accepted as basic the idea of provinces as the contracting parties. Though after the BNA Act went into effect differences of opinion arose among the provinces over the pact concept, it "has always been the principal buttress of provincial autonomy"7 and is relied on particularly by Quebec in its insistence on a special place in confederation.

How important the idea of a compact of contracting provinces as the basis of a state is to the amour propre of those provinces can be understood more clearly when Canada is compared to the United States. The Federalists, who carried the day at the Constitutional Convention of 1787, rooted the American Constitution in the consent of the people, a concept whose challenge to the states was immediately obvious to the Antifederalists. The Convention, Patrick Henry noted, spoke "the language of, We, the people, instead of, $W e$, the states. "8 Indeed, that is precisely what the Constitution accomplished, Alexander Hamilton rejoiced in The Federalist No. 22.9 Though Jefferson and others were later to insist on referring to the Constitution as a compact to which the states had acceded as states, ${ }^{10}$ the idea never won wide acceptance and was finally laid to rest in 1869 by the U.S. Supreme Court in the landmark case Texas $v$. White. ${ }^{11}$ The Court noted that the act "which consummated [Texas'] admission into the Union was something more than a compact; it was the incorporation of a new member into the political body."12 What the Constitution had wrought was a complete and indissoluble union. ${ }^{13}$ Thus, the Americans opted for something quite different from the Canadians. The American Constitution is founded on popular sovereignty, the BNA Act on provincial power.

In addition to being the midwives at Canada's birth in 1867, the provinces became increasingly influential in charting the course of Canada's growth into

3. Id, at 107 .

4. Id. at 108 .

5. Id.

6. Id. at $108-09$.

7. Id.

8. 3 The Debates in the Several State Conventions on the Adoption of the Federal CONSTITUTION 22 (J. Elliot 1901).

9. The Federalist No. 22, at 146 (A. Hamilton) (J. Cooke ed. 1961).

10. Jefferson's clearest statement of the idea is in the Kentucky Resolutions of 1798 , which he drafted.

11. Texas v. White, 74 U.S. (7 Wall.) 700 (1868).

12. Id. at 726 .

13. Id at 725 . 
adulthood. The provinces, for their own self-protection and advancement, chose in 1867 to devise a system in which the central government would have considerable power. Thus not only did the BNA Act vest in the national government a great many important legislative powers in section 91 , it also lodged power in the central government to appoint provincial lieutenant governors, judges of the higher provincial courts, and members of the Senate from the provinces; gave the central government power to reserve or disallow any provincial legislation within a year of its passage; and enabled Parliament, under certain circumstances, to enact remedial legislation affecting the status of separate schools in a province. As Norman Ward concluded, "the British North America Act certainly intended to establish . . a . . system . . . in which the Dominion government was to be paramount." 14 And in fact a period of nation-building was entered into after 1867 on the basis of section 91 , which brought the national government for a while into paramountcy among Canadian governments. In the process, the foundation for modern Canada was laid.

Even so, time was on the side of provincial power. To draw from Norman Ward on the point, the eventual development of responsible government in ten provinces "inevitably led to centralism within each province, and hence to rivalry with the Dominion." Moreover, the addition between 1870 and 1949 of only a few large provinces rather than of many smaller ones "minimized the Dominion government's opportunities either to dominate the provinces, or to play them off against each other . . . ." And the "mere problem of space" in so large a territory as Canada inevitably made Ottawa remote from much of the country and enhanced "the importance of provincial capitals . . . ." Perhaps the final blow to central dominance was the discovery and exploitation of natural resources in the provinces "and the rise of powerful industries based on them," the regulation and control of which were not among the powers bestowed on the national government in section 91. "And to these comprehensible economic and political elements must be added the mysteries of judicial decision," which steadily reduced Parliament's power, "while the powers of the provinces were at the same time steadily extended," generally under the property and civil rights clause in section 92 of the BNA Act itself. ${ }^{15}$

In short, as the conditions which led the four founding provinces to demote their own power in 1867 changed, as new political and economic conditions which

14. Ward, The Structure of Government, in The CANadians 1867-1967, at 29 (J. Carclass and R. Brown eds. 1967).

15. Id. at 29-30. As Henry Albinski put the same point:

For nearly a generation the Privy Council followed the intentions of the Canadian founders, allowing the central authorities considerable latitude. A generous definition was accorded to the BNA Act clause that invested Ottawa with responsibilities over the "Peace, Order, and good Government of Canada." Then the Privy Council shifted its attention to Section 92 of the BNA Act, in which "Property and Civil Rights in the Provinces" were listed as among the areas of exclusive provincial jurisdiction. It came to insist that the jurisdictional domain of any particular enactment be construed according to whether in "pith and substance" its actual effect was to trench upon "property and civil rights." Thus "property and civil rights" were given very wide application, and generally superseded the "peace, order, and good government" entitlement of the federal government.

H. Albinski, Canadian and Auștralian Politics in Comparative Perspective 362 (1973). 
called for exertions of provincial power developed, and as judges, over time, began to read the BNA Act differently, the coin of the Canadian state was flipped. As Cole Harris has summed it up:

[T] he growing role and visibility of the provinces and of provincial governments . . . [took] place while governments were assuming a larger role in Canadian life and while the evolution of the Canadian economy was changing the significance of some of the terms of the British North America Act. In an age of water power and steam, control of natural resources did not mean what it does today. Provincial governments ... assum[ed] a growing role in the economy, and the province a growing role in Canadian feeling. A host of activities that once were organized at many [local] scales [came to be] organized provincially. At the same time federal power . . . also increased, as Ottawa, too . . . expanded its services and its economic presence. In short, provincial and federal governments [grew] simultaneously at the expense of a multitude of other scales of Canadian interaction. This [was] a recipe for conflict. It reduce[d] a whole gamut of different relationships at different scales to a polarized struggle between two levels of government. ${ }^{16}$

Through the years the provinces more often than not were the victors in that struggle, while the power of the central government was diminished. War and depression in the twentieth century temporarily halted-and even reversed-the movement, but after World War II, it resumed with even more vigor.

Thus as the provinces approached the table to negotiate the patriated constitution with the federal government in 1980 , they did so with a long tradition of provincial power behind them. They could hardly be expected to abandon that position as the negotiations proceeded.

The provinces had even more at stake at the bargaining table than preservation of the compact notion and continuation of their eminence in the exercise of governmental power, for they also had a vested interest in the process of intergovernmental consultation to defend. The federal-provincial conference had become, especially after World War II, the standard way of dealing with most important domestic policy questions which arose for governmental action. Whether it is a first ministers' (the Prime Minister and the provincial premiers) conference, a conference at the ministerial or departmental level, or one of a variety of special ad hoc intergovernmental conferences, Canadian domestic policymaking remains by and large the product of conference negotiation.

With increasing frequency in recent years, the provinces have taken the initiative in setting the agenda for federal-provincial meetings. Very often the end product is a bilateral agreement between Ottawa and a single province, though multi-governmental agreements are not uncommon. The provinces favor the process since each of the bargaining sessions is sui generis, often providing opportunities for particular provincial interests to be advanced. ${ }^{17}$ Indeed, as Gordon

16. Harris, The Emotional Sinuture of Canadian Regionalism, in THE Challenges Of CanadA's REgIONAL DIVERSITY 28 (1981).

17. Roger Gibbins points out, however, that while federal-provincial conferences do provide, undoubtedly, a badly needed forum for the representation of provincial interests . . . there are many definitions of "the provincial interest," depending on who is consulted: provincial voters, provincial governments or provincial representatives in the federal cabinet . . . Within any single province definitions will differ among voters, interest groups, provincial parties, federal MPs and federal cabinet representatives. Thus it would be a mistake to accept uncritically the rhetoric of the provincial governments and to assume that they speak in the provincial interest.

R. Gibbins, Regionalism, Territorial Politics in Canada and the United States 96 (1982). 
Robertson, speaking out of his long intimate personal experience as a federal bureaucrat involved in the intergovernmental consultation process, put it recently, federal-provincial meetings have tended to become occasions "for the articulation of distinct provincial interests and for provincial intrusion into wholly federal areas of concern." 18 His observation was underscored by Michael Kirby, who was once secretary to the cabinet for federal-provincial relations: "Provinces, like individual citizens, are . . . tending to take an individualistic rather than a collective view of the country . . . on a scale that is unprecedented in Canadian history." 19 Alberta's protracted quarrel with Ottawa over an oil-pricing agreement is a specific example of Kirby's point. But a number of the other provinces approach bargaining with the federal government from a similarly self-centered position; even a "have-not" province like Newfoundland, under its feisty premier Brian Peckford, is learning how to get the most for itself out of negotiations with Ottawa.

The importance of the federal-provincial conference to the provinces, however, is not only that it provides a mechanism for provincial governments to be effectively involved in the handling of the important public policy issues, but also that it "has facilitated the adaptation of parliamentary procedures to a federal system ...." Each conference aims at reaching "mutual agreement." These agreements, numbering in the thousands, enable the Canadian system of government to work. They permit the partial acceptance of both centralist and regional viewpoints and reject "the idea that either one embodies the whole truth." 20 As such, the federal-provincial conference has been an admirable way over the years to settle most of the division of power issues that have arisen between Ottawa and the provinces.

Thus the provinces in Canada have come to occupy a powerful position in Canada's governmental matrix, both in fundamental power within confederation and in the procedure for developing public policy to convert that power into programs. It was from this position that they approached the challenge Prime Minister Trudeau gave them when he presented the fait accompli of a reformed constitution.

This is not the place to chronicle the events of the constitutional battle of 1980$81 .{ }^{21}$ Suffice it to say here that on a number of crucial points the provincial premiers forced Prime Minister Trudeau to yield to their demands. Thus the draft finally sent off to London could rightly be considered as representing provincial interests-or at least those of the governments in power in nine of the ten provinces (Quebec never accepted the draft Constitution). Now that the patriation process is over, those nine provincial governments might be expected to be looking forward to living with the product of their labors happily ever after.

That expectation, however, is probably ill-founded. The acceptance of the

18. Gordon Robertson, quoted in CONFRONTATION AND COLlaboration-INTERgovernMENTAL Relations in Canada Today 82-83 (R. Simeon ed. 1979).

19. Lecture by Michael Kirby, Carleton University, Ottawa (April 1980), quoted in The Financial Post, May 3, 1980, at 7, col. 1, 4.

20. Elton, Placing Constitutional Reform in Perspective, 2 Spectrum 6 (1981).

21. See the contribution to this volume of Mallory, The Politics of Constitutional Change, LAw \& CONTEMP. Probs., Autumn 1982, at 53. 
reformed constitution by the provinces will vary from province to province. Quebec provides the extreme case. She stands adamant on her rejection of the reformed constitution. Quebec's leaders oppose it, first of all, on general grounds as an improperly drawn up document that violates Canadian "constitutional conventions." The provincial government brought an action in the Quebec courts contending that the province has a right to veto a major constitutional change affecting provincial jurisdiction. The Quebec Court of Appeal ruled early in April 1982 that the province had no such right. ${ }^{22}$ Quebec immediately appealed to the Supreme Court of Canada. The Court dismissed the appeal. ${ }^{23}$

In arguing its case before the Supreme Court, Quebec predictably contended that Canada is the product of a political compact between its two founding language groups and that no changes in the existing constitution (the BNA Act) can be made without Quebec's agreement in behalf of the Francophone group. The province also objected to several of the particulars of the 1982 Constitution: the elimination of financial compensation to provinces which choose to opt out of federal programs, the asserted right of mobility for workers across Canada, and the protection of language rights for the Anglophone minority within Quebec. In short, Quebec is concerned that it will lose its special status in confederation. Quebecers see this status as having been ravaged, especially by the Charter of Rights, which Premier René Lévesque refers to as "the contraption that's called the bill of rights."'24

Ottawa has maintained a standing offer to resume constitutional negotiations with Quebec on the points of contention, but provincial leaders have not so far indicated any willingness to accept the offer. Far from manifesting a conciliatory attitude, Quebec's stance has become increasingly strident. Not only did Lévesque and leaders of the Parti Québécois boycott the formal promulgation ceremonies in Ottawa and stage a counter-demonstration at home, but Premier Lévesque "refused to rule out the possibility of individual acts of civil disobedience on the part of members of his government" after the constitution came into effect "and admitted that withholding tax transfers to the federal government" was not out of the question. ${ }^{25}$ At the very least, Premier Lévesque promised that his government will make maximum use of the constitution's notwithstanding clause (section 33). ${ }^{26}$ Bill 62, enacted by the Quebec National Assembly in early summer 1982, asserts that Quebecers' fundamental freedoms and rights are subject only to the provincial charter of rights, not to the constitution's Charter of Rights, and that the education provisions of Quebec's Charter of the French Language (Bill 101) will continue to be applied in the province rather than the parallel but different provision in the new constitution. By taking such actions, Quebec made sure that in Premier Lévesque's words, there will be "a lot of judicial muddling." In any case, the Premier promised, "we're working like mad at whatever can be done to

22. Re Attorney Gen. Que. \& Attorney Gen. Can., 134 D.L.R.3d 719 (1982).

23. Re Attorney Gen. Que. \& Attorney Gen. Can., 140 D.L.R.3d 385 (1983).

24. Quoted in Globe \& Mail, Mar. 30, 1982, at 1, col. 1, 3.

25. Id.

26. For an explanation of the notwithstanding clause, see infra note 35 and accompanying text. 
counter the bloody thing." 27

Thus Quebec's future within confederation remains unclear. The ruling Parti Québécois has pledged to make sovereignty for Quebec the main issue in the next provincial election, which is not likely to take place for another two or three years. Premier Lévesque let himself be quoted in early June 1982 as saying that "with another push" Quebec would become independent by the end of the decade. ${ }^{28}$ In the interim, Quebec, Canada's second largest province, is in constitutional limbo.

Not to belabor the point of different provincial reactions to the reformed constitution, it need only be said that the energy-rich provinces of Alberta and British Columbia can be expected to regard the reformed constitution from a different perspective than the other provinces because of section 50, which amends section 92 of the BNA Act with regard to power over non-renewable resources by shifting responsibility therefor to the national government. Similarly, the perspective of the Atlantic provinces will be skewed by the long dependence of that area on federal payments from Ottawa. And with provincial governments likely to remain of different political persuasions from the federal government-seven of the provinces in 1982 were under Progressive Conservative governments, one was under a NDP government, one under a Social Credit government, and Quebec, of course, under the Parti Québécois_a variety of perspectives toward the reformed constitution is to be expected.

The expectation of the continuation of a strong provincial presence in Canadian governmental affairs under the reformed constitution is further brought into doubt when the nature of the document itself is considered. One "disturbing aspect" of the whole process by which constitutional reform was achieved, Terrence G. Carroll concluded, "was the bargaining and horse-trading which took place" in the course of negotiations. "Proponents of a system of elite accommodation will properly point out that all of [the changes which resulted from the bargaining] represented a willingness to compromise and a real commitment to reach an agreement on the side of the political leaders of the country." But the other side of the coin was perhaps, Carroll thought, a weakening of public support for the constitution. The public was forced to witness a "conference at which the 'fundamental rights' of Canadians, and the 'fundamental rule' of the Canadian political system, changed hour by hour."

If a constitution is to be effective it must be widely believed to embody the highest form of human law. It must be thought to represent the best interests and the best instincts of the society. It is unlikely that the Canadian constitution can quickly regain this status as a result of a complicated compromise arranged entirely by the political elite. ${ }^{29}$

Not only is the reformed constitution thus perhaps weakly rooted in popular acceptance, but much of its contents seem tentative or transitional in nature. In fact, perhaps one ought not to use the word constitution without quotation marks around it to indicate that it is not really a full-blown constitutional document, any more than was the BNA Act of 1867. Indeed, the BNA Act (now to be called

27. Quoted in Globe \& Mail, Mar. 30, 1982, at 1, col. 1, 3.

28. Globe \& Mail, June 10, 1982, at 4, col. 4.

29. T. Carroll, Political Participation 88 (1982). 
Constitution Act, 1867) is fully incorporated into the patriated constitution, to be sure with some important new provisions. Not only is the new constitution also "merely a British statute," presented to Parliament after "little public debate, and [with no] endorsement by the electorate,"30 but by its very terms it is incomplete and open-ended. It not only assumes that a great many amendments will be made in its text in forthcoming years-indeed, the nature of the amending process was one of the stickiest points in the negotiations leading up to the final agreementbut it calls in section 37 for a constitutional conference, "composed of the Prime Minister and the first ministers of the provinces," to be convened by the Prime Minister within one year after the Canada Act comes into force. Though the intention of the section seems to have been to provide a way to settle the rights of Canada's native peoples, an issue left unresolved in the negotiations process, the terms of section 37 require only that the conference "shall have included on its agenda an item" concerning native rights. The conference agenda, which presumably will be drawn up conjointly by the two levels of government, may be much longer-section 37 also speaks of "discussions on any items on the agenda."

The first "section 37" conference was held on March 15-16, 1983. It dealt with the narrow question of native peoples' claims that they were never properly compensated for the lands taken from them by the French and English settlers. No consensus was reached on the matter by the ten provincial premiers and Prime Minister Trudeau attending the sessions, and other agenda items were disallowed. Presumably other constitutional conferences on native rights will be held in the future.

The reformed constitution was also left open-ended by section 49 , which provides that another "constitutional conference" is to be called by the Prime Minister within fifteen years, at which he and the provincial premiers will "review the provisions" of Part V, which is concerned with procedure for amending the constitution. The lack of agreement on an amending formula undoubtedly prevented earlier patriation of the constitution to Canada. The question is whether the 1981 version will turn out to be any more satisfactory than the earlier rejected formulae. ${ }^{31}$ As Alexander Brady wrote years ago: "In a liberal federation . . the devising of a satisfactory procedure for amendment is rarely easy and seldom gives satisfaction." 32

Other parts of the reformed constitution threaten to diminish provincial power by shifting responsibility to the national government. These include the guarantee in sections 25 and 35 of the rights of aboriginal peoples, and the provisions in sections 50 and 51 amending section 92 of the BNA Act with regard to power over non-renewable natural resources, forestry resources, and electrical energy.

Special mention must be made of section 36 , which commits both the provinces and the national government to the principle of equalization, specifically to

(a) promoting equal opportunities for the wellbeing of Canadians; (b) furthering economic

30. R. GibBins, supra note 17 , at $28-29$.

31. See the contribution to this volume by Dellinger, The Amending Process in Canada and the United States: A Comparative Perspective, LAW \& Contemp. ProbS., Autumn 1982, at 283.

32. Brady, Constitutional Amendment and the Federation, 29 CAN. J. ECON. \& POL. SCI. 486 (1963) 
development to reduce disparity in opportunities; and (c) providing essential public services of reasonable quality to all Canadians.

The national government is further committed under section 36 to "the principle of making equalization payments to ensure that provincial governments have sufficient revenues to provide reasonably comparable levels of public services at reasonably comparable levels of taxation." Only time will tell what becomes of these principles in application. The wording of the first part of the section raises doubts in some minds as to its justiciability. "Without altering the legislative authority of Parliament or of the provincial legislatures, or the rights of any of them with respect to the exercise of their legislative authority," reads that section, "Parliament and the legislatures, together with the government of Canada, are committed" to equalization. That wording alone supports the judgment of Professor Thomas Courchene that the Canadian courts will ultimately have to become "the final arbiter" of what actions qualify as constitutional steps toward fulfilling that commitment, as indeed the courts will also become in determining what would be a "reasonable" equalization formula under the second part of section $36 .{ }^{33}$ How the provinces will fare under judicial rulings is a matter of conjecture.

Similarly, the impact on the provinces of the centerpiece of the reformed constitution, its Charter of Rights, is a matter of conjecture. As with the equalization provision, Charles Campbell has concluded, "the main effect of the Charter will be to strengthen the role of the courts as a procedural policeman." ${ }^{34}$ Already a spate of challenges to the Charter has been made in provincial courts. If Canadian experience follows that of the United States, judicial interpretations of federal versus provincial power over rights will be inconsistent. The Canadian experience will be complicated by the terms of the compromise that had to be included in the Charter in the form of the "notwithstanding" clause, which was intended to accommodate provincial uneasiness. This clause provides that provincial legislatures may override for five years (and longer if the override legislation is renewed) the Charter's provisions in the areas of fundamental freedoms (such as freedom of assembly, press and belief), legal rights (such as the prohibition of the use of illegally obtained evidence in court), and anti-discrimination guarantees. On the one hand, different reactions by individual provinces may be expected-the NDP government of Manitoba early said that it would not use the override provision-thus making any unified provincial position on rights highly unlikely. On the other hand, a Canada-wide statement of rights may in the long run be a strong force for nationalization. As the eminent Canadian political scientist, Donald Smiley, concludes, there will inevitably be "a disposition to change the Canadian political system and political culture in a fairly fundamental way by inducing Canadians to identify themselves and to frame their allegiances in terms of their rights as protected by national institutions, and thus the ongoing provincialization which has become so pervasive will be weakened." 35

33. Quoted in More Storm Clouds, Alberta Report, April 10, 1981, at 3.

34. Campbell, Charter of Rights Could Lead Courts into a Political Role, Globe \& Mail, Feb. 18, 1982, at 7, col. 1,5 .

35. Smiley, A Report to the Ontario Economic Council, quoted in Globe \& Mail, Nov. 2, 1981, at 7. 
Attention should also be paid to section 42, which alters the BNA Act's provision for admitting new provinces. Whereas the BNA Act left it up to negotiation between a territory and Ottawa, the patriated constitution allows a province to be created or to expand only by gaining the approval of the federal government and of at least six provinces containing in the aggregate half of Canada's total population. The effect of that provision may soon be tested. Even prior to the proclamation of the constitution, a plebescite was held in the Northwest Territories in which fifty-six percent of those voting approved splitting the territories into two parts, roughly corresponding to the Inuit and Dene populated areas there. Although it is not binding, the plebescite is widely regarded in the North as "the first step in the creation of at least two new northern provinces." 36 There are questions, the Globe and Mail observed editorially, "about whether the division would make Ottawa more reluctant to grant provincial status to the Northwest Territories. Anything that would postpone this political maturity would be unfortunate," 37 particularly in light of the possibility that if the territories are not given self-government, "chunks of land could be swallowed by [provinces to] the south. . . . But it should be remembered that Nunavit [the name given to the Inuit portion of the area] is almost twice as populous as Manitoba was when it gained provincehood in 1870."38 The impact of new provinces on the existing provinces and on the balance of power between the provinces and Ottawa is hard to assay. They would very likely add weight to the provincial side.

Finally, municipal governments, long at the bottom of the totem pole of governmental power and recognition in Canada, have in recent years increasingly asserted their desire to obtain formal constitutional status. As the details of the patriated constitution were being worked out in 1980 and 1981, municipalities repeatedly attempted to achieve that goal. They did not succeed, but they remain determined, even though they were chastised by Governor-General Edward Schreyer for taking that stand. In an address to the 1982 conference of the Federation of Canadian Municipalities in Ottawa, the governor-general, himself a former provincial premier, decried the idea as unduly complicating the formal order and structure of the nation. In any case, he doubted if anything like a consensus among provinces could be obtained to support the objective of municipal government. There is the possibility that municipalities would settle for a constitutional statement of the national government's responsibility for achieving balanced urban growth and development, but that too promises difficulties. Either answer to the municipalities' prayers would cause a shift in provincial power.

Thus by conference, amendment, interpretation, and legislative action over time, the position of the provinces under the 1982 constitution may be altered. A different balance may also be struck as the provinces, with the national government, explore ways of settling a wide variety of issues that have eluded resolution in recent years. The real test of the new constitution, indeed, may be in how well it serves the nation in making resolution of those issues possible. Certainly at first

36. Johnson, First Step on the Road to Two New Provinces?, Globe \& Mail, Apr. 7, 1982, at 7, col. 2.

37. Globe \& Mail, Apr. 8, 1982, at 6, col. 5 .

38. Id. at col. 6 . 
glance the 1982 constitution does not seem to change the context within which resolution will occur. Among the issues the provinces wish to see resolved by some combination of governmental action are the pricing of oil, about which Alberta is still unhappy; control of telecommunications, in particular of cable and pay television; revision of anti-combines legislation; jurisdiction over offshore seabed resources and fisheries, an unresolved issue since at least 1949 and currently the major squeak point in the relations between Newfoundland and Ottawa; the propriety of national versus provincial lotteries; the establishment of uniform education standards across Canada; the removal of economic barriers to the free movement of goods, labor, and production factors across provincial boundaries; provincial versus national responsibility for energy policy; and the abandonment of the Crow's Nest Pass Agreement of 1897, under which western grain producers have been guaranteed cheap transportation by rail of their products to market.

While these issues are important, they pale in significance beside the settlement of the basic fiscal arrangements between the national government and the provinces, including arrangements both for collecting income taxes and for transferring funds from Ottawa to the provinces. Negotiations on these matters between the provinces and Ottawa for the five year period 1982-87 broke down in the winter of 1982, and Ottawa unilaterally enacted a set of arrangements. Although the arrangements will likely stand, and although the provinces will fare somewhat better over the period than they had expected, the provinces were unhappy with Ottawa's action, especially the dependent-on-Ottawa Atlantic provinces. In the next round of discussions the provinces will probably exert themselves more strongly than ever upon the resolution of these basic fiscal arrangements.

In the long run, it may appear that the reformed constitution itself is not cast so as to provide Canada with the kind of underpinning required for future national development. Except for the resource changes mentioned above, sections 91 and 92 stand in the reformed constitution even as they stood in the BNA Act, still food for negotiation and eventually, for parts of them, grain for the judicial grist mill, with no sure provincial or national advantage. As Eugene Forsey summed it up, "This is not a new constitution. It's the old constitution with some very important additions. There will be the same questions. Does this come under section 91 or 92 ? Does section 93 apply?"39 In short, the new constitution does not get at the heart of the matter, the existing division of power between the national government and those of the provinces. In particular, it does not address the constitutional distinction made in the BNA Act between direct and indirect taxes, nor does it deal with the harmonization of national and provincial taxes in general. More broadly, the reformed constitution does not take into account "the economic imperatives" of the modern technological state which "require unified if not uniform economic policies throughout the entire territory [of a state] and do not brook that kind of economic fragmentation" so characteristic of Canadian federalism in the past. ${ }^{40}$

39. Quoted in Graham, Happy and Glorious, SAT. NiGHT, June 1982, at 30.

40. Lowenstein, Reflections on the Value of Constitutions in Our Revolutionary Age, in CoNSTITUTIONS AND Constitutional Trends Since. WORld War II 191, 211 (A. Zurcher ed. 1951). 
Indeed, the economic power of Alberta, and to a lesser extent, the other resource-rich provinces, challenges the efficiency of policy making by the national government and even of national leadership itself. At the very least, the interests and objectives of those provinces clash with those of the other provinces. It is unclear, in any event, how the new constitution will address the need for a new balance between those provinces and Ottawa and between them and their sister provinces. Nor is it clear how the new constitution speaks to the solution of any of the problems alluded to earlier.

All that can be done at this juncture is to wait and see. Canada's new constitution, like that of the United States in the early days, will only be a paper contrivance until time and experience have filled out its meaning.

Even more important than the impact of unsolved problems on constitutional development is the necessity many feel for fundamental reform in Canada's political institutions, changes which were avoided in the constitutional negotiations of 1980-81. Some proposed basic constitutional changes might increase provincial power. One proposed change would provide for an elected rather than an appointed Senate, a Senate which would not be "irrelevant," but which would perform the important function of providing a place where regional voices might be heard at the center:

[W] here other federations have an elected second chamber to provide regional voices for their constituents, our Constitution has provided, effectively, nothing but a vacuum. It is a vacuum that has, of necessity, been filled extra-constitutionally ... [by] provincial Premiers . . . step[ping] forward as spokesmen for their provinces on national issues. [But] provincial premiers are elected on provincial issues, to run provincial governments . . . . They are not elected for their views on national issues. ${ }^{41}$

The members of a reformed Senate would perhaps be elected by proportional representation. Quebec could possibly be given a set percentage of seats to protect its special status in confederation, and the smaller provinces could have delegations disproportionately larger than their populations, to compensate for their smaller representation in the House of Commons. A reformed Senate would probably be accorded only limited legislative authority, not the full equality with the House which the American Senate enjoys with the House of Representatives, out of respect for the parliamentary system's reliance on confidence in the House of Commons for responsible government. The Senate's role would be to increase the weight of regional considerations in parliamentary deliberations. In particular, Gordon Robertson believes, an elected Senate in place of the present one might reduce "the sense of alienation and frustration in the West toward the federal government."42

A second proposed basic structural change, not incorporated into the reformed constitution, is some sort of proportional representation scheme for elections to the House of Commons. The "first-past-the-post" electoral system traditionally

41. Kent, How to Enjoy Regional Diversities, in The Challenges of Canada's Regional Diversity 40 (1981).

42. Quoted in The Institule, vol. 4, no. 2, Feb. 22, 1982, at 1. But see Fisher, Personal Viewpoint: Senate Keform, EXECUTIVE, Mar. 1982, at 81-82, who argues against any immediate change in the composition of the Senate. 
employed in Canada has resulted in recent years in exclusion of "even the major parties from representation in certain regions of the country. As the [1979 and 1980] federal elections have shown, it is becoming increasingly difficult for any party to form a government with representation from all regions of the country."43 Thus there is no surety that regional interests will be weighed as they should be in "the determination of programs, policies and priorities" in the House. Only if the method of representation is revised, it is argued, will parties be enabled to participate in a process of national consensus-building "which is not a sham but an active process in which regional diversities are acknowledged, assessed, in reason reconciled and for the successful party, integrated into policies that earn national confidence." 44

In any case, the 1981 census will result in a realignment of the House of Commons. The membership of the House will rise to 310 at the first federal election after 1984. Added to that chamber then will be additional representatives from disaffected Quebec (6) and Alberta (6), as well as from Ontario (10) and British Columbia (5). This may improve regional representation in the House to some degree; even so, because of the constitutional necessity of overrepresenting the smaller provinces, ${ }^{45}$ those four provinces, which contain $82.3 \%$ of the 1982 population, will even then have only $78.7 \%$ of the seats in the House.

A third suggestion for basic constitutional change, also not incorporated into the reformed constitution, would affect the well established pattern of intergovernmental consultation already referred to in this paper. ${ }^{46}$ As the government of British Columbia pointed out in its 1978 series of Constitutional Proposals, the overall intergovernmental negotiation process is a piecemeal one, "with little regard for long-term objectives and priorities," consisting as it does of a "rather nebulous clutter of committees . . . often without consistent objectives or formal organization . . . [; too] little attention [has been] paid to coordinating the activities of [this] vast network of . . . meetings and conferences" across the wide range of policy areas involved. ${ }^{47}$ Moreover, one set of participants in that process

has been elected on issues in federal jurisdiction, the other ten on issues in the jurisdiction of [the] province[s]. They meet to argue, negotiate and, desirably, co-operate in the many matters that involve both jurisdictions. [But] they must . . . be true to their watching constituents on issues for which they were elected . . . . None of the participants has legitimacy as a spokesman for regional or provincial viewpoints on federal issues. ${ }^{48}$

In the view of some, a reformed Senate might take the place of some of the intergovernmental consultation process; or it could be regularized and brought into

43. Notes for Remarks by the Prime Minister [Pierre E. Trudeau] at the Tenth Anniversary of the Council of Maritime Premiers, Fredericton, New Brunswick, June 1, 1981, at 23. (Photocopy supplied to the author by the Canadian Embassy in Washington.)

44. Kent, supra note 41 , at 46.

45. Prince Edward Island with four representatives for its roughly 120,000 people is the example par excellence of overrepresentation.

46. See supra notes 17-20 and accompanying text.

47. Province of British Columbia, British Columbia's Constitutional Aropasals, Paper No. 5, "Improved Instruments for Federal-Provincial Relations," Sept. 1978, at 7-11.

48. Kent, supra note 41 , at 41 . 
some semblance of order through specific constitutional provisions governing its conduct. However, David Elton argues,

this type of reform should not be confused with, or substituted for, increasing the ability of national institutions to cope with regional diversity; intergovernmental mechanisms are not sufficient for this purpose. The institutionalization of federal-provincial conferences, without the reform of central government institutions in the direction of more effective regional representation, could further erode the credibility and capacity of the national government. ${ }^{49}$

Other proposed reforms include changing the basis of appointment of Supreme Court justices and improving regional representation on regulatory agencies of the national government, so that they too would better reflect provincial interests.

Finally, a set of issues put on the constitutional agenda as long ago as October 1976 by the provincial premiers remains unresolved. These issues include the national government's declaratory and spending powers, its moribund but still extant power to reserve or disallow provincial legislation, its power to implement treaties, and its residual power in general. Also left unaddressed are the issues put forward by the First Ministers' conference of February 1979: empowering governments adequately to fight inflation and unemployment; dealing with non-tariff barriers to interprovincial and international trade; providing for the regulation of the Canadian securities market; and dealing with the role of commodity marketing boards.

Whether any of these issues will win a place on the agenda of future constitutional conferences seems unlikely. One point, however, which is not arguable is the necessity of eventually facing most of these issues.

\section{CONCLUSion}

In their national political institutions, Canadians have tried to combine parliamentary and federal forms of government. But, as Roger Gibbins so effectively put it, parliamentarianism has "dominated and, as a consequence, national institutions have become too majoritarian in character, too insensitive to the diverse and pluralistic interests of a federal society." In particular, the traditional institutions of the national government, which remain unchanged in the 1982 version of the constitution, "have not facilitated the effective representation of territorial interests . . . Parliamentary norms and the tightly disciplined party system they [engender bottle] up territorial conflict and [deny] it an effective outlet through the institutions of the national government. . . ." The Senate has never been a useful "forum for the protection and promotion of territorial interests," and in the House of Commons, the "less populated sections of the country [have been] outgunned and overrun in national politics when regional MPs found themselves on the wrong side of the party fence." Such ineffectual "territorial representation within the national government," Gibbins concluded, "has led to constitutional turmoil and uncertainty .... ."50

In the constitutional negotiations leading up to the constitution of 1982, the

49. Elton, supra note 20 , at 11 .

50. R. GibBins, supra note 17 , at 78 . 
issue of the lack of adequate regional representation within the institutions of the national government was sidestepped in favor of what were thought then to be even more important problems-securing a constitutional basis for Canadians' rights and a workable amendment process. Thus the new constitution, like the BNA Act it incorporates, leaves territorial conflict to be resolved almost exclusively by provincial governments. "The inability of the Canadian political system to handle territorial conflict effectively has in turn weakened its ability to handle other issues, as the contemporary energy and budget disputes between Ottawa [and the provinces] so clearly illustrates." 51 Change in these institutions will not be easy. Yet, the argument for change is a valid one, and the need to act on it is impelling.

The reformed constitution, in fine, as embodied in the Canada Act of 1982, should be regarded as the product of only the first phase of constitution-making in Canada. The struggle for power between Ottawa and the provinces has not been ended by its proclamation. Open-ended as the reformed constitution is, the balance of power is very likely to change considerably in the years ahead. Whether the change will favor the provinces or Ottawa depends on a number of variables which will be brought into play over time by the federal cabinet and Parliament, provincial premiers and legislatures, judges of courts of appeal and the Supreme Court of Canada, and federal and provincial bureaucrats. It is even possible that the Canadian people might eventually insist on having an input. And in the longer run, if constitution-making goes on to include some or all of the basic institutional changes just discussed, the final balance may be different still. As Roger Gibbins reasoned: "The creation of more effective means of regional representation in Ottawa would . . . weaken the power of the provincial governments," at the same time weakening "the power of the federal cabinet over national institutions." As he sees it,

At heart, the traditional degree of cabinet control and effective territorial representation are
incompatible. . [I]f the federal cabinet is weakened by institutional reform while the
control of provincial cabinets over their own legislature is not similarly reduced, if majori-
tarianism is reduced within the national government but not within the provincial govern-
ments, then in the short run the federal system may be further destabilized in the direction
of greater devolution and provincial strength . . [O]ver the long run, more effective
regional representation will strengthen the position of Ottawa vis-a-vis the provinces, even
though the federal cabinet's power within Ottawa would be diminished. ${ }^{2}$

Thus the new constitution's impact on Canadian federalism will be long in being felt. But that was to have been expected. As David Elton reminds us,

[I]t should not be thought that an end to the debate on patriation, amending formulae and a charter of rights and freedoms will [have] conclude[d] the debate on constitutional reform in this country. Quite the contrary. Constitutional issues will continue to force themselves onto the public agenda and take precedence over other issues until such time as the structural framework of Canadian federalism has been adjusted to reflect the regional realities of Canada. ${ }^{53}$

What adjustments in the federal-provincial balance may finally result cannot

51. Id. at 194.

52. Id.

53. Elton, supra note 20 , at 3 . 
be predicted with any surety. One thing, however, is sure: the flexibility and durability of the Canadian federal system will be put to the test in the years ahead. The likelihood is great that it will survive that test and be with us into the indefinite future. 